\title{
TRATAMENTO DE ESGOTO SANITÁRIO UTILIZANDO REATORES ANAERÓBIOS OPERADOS EM BATELADAS SEQUENCIAIS (ESCALA PILOTO)
}

\section{DOMESTIC SEWAGE TREATMENT IN PILOT-SCALE ANAEROBIC SEQUENCING BATCH REACTORS}

\begin{abstract}
ARNALDO SARTI
Engenheiro Químico (UFSCar). Doutor em Engenharia Civil - Departamento de Hidráulica e Saneamento. Pós-Doutor do Departamento de Hidráulica e Saneamento (EESC/USP)

\section{ISABEL KIMIKO SAKAMOTO}

Bióloga (FFCLRP/USP). Doutora em Engenharia Civil (EESC/USP). Pós-Doutora do Departamento de Hidráulica e Saneamento (EESC/USP)

\section{MARIA BERNADETE AMÂNCIO VARESCHE}

Bióloga (UNESP/Botucatu). Doutora em Engenharia Civil (EESC/USP) - Departamento de Hidráulica e Saneamento. Professora do Departamento de Hidráulica e Saneamento da EESC/USP

\section{MARCELO ZAIAT}

Engenheiro Químico (UFSCar). Doutor em Engenharia Civil - Departamento de Hidráulica e Saneamento. Professor do Departamento de Hidráulica e Saneamento (EESC/USP)

\section{EUGENIO FORESTI}

Engenheiro Civil (EESC/USP). Doutor em Engenharia Civil (EESC/USP) - Departamento de Hidráulica e Saneamento. Professor Titular do Departamento de Hidráulica e Saneamento (EESC/USP)
\end{abstract}

Recebido: 05/08/05 Aceito: 14/02/06

\section{RESUMO}

Avaliou-se o desempenho de dois reatores anaeróbios operados em bateladas seqüenciais $\left(1,2 \mathrm{~m}^{3}\right)$ diferenciados pelo tipo de imobilização de biomassa, na forma de suporte inerte e de biomassa granular no tratamento de esgoto sanitário do Campus da USP de São Carlos. O monitoramento ao longo de 70 dias de operação revelou similaridade no comportamento das configurações ensaiadas, que apresentaram eficiências médias de remoção de DQO e sólidos suspensos ao redor de 60\% e 75\%, respectivamente. Por meio de técnicas de biologia molecular constatouse diferenças na comunidade bacteriana nos reatores no $35^{\circ} \mathrm{e}$ $70^{\circ}$ dias de operação, indicando que a imobilização de biomassa selecionou populaçōes bacterianas diferentemente. Em relação ao domínio Archaea houve maior similaridade, provavelmente, pelo fato desses microrganismos utilizarem substratos específicos ao final do processo anaeróbio.

PALAVRAS-CHAVE: Esgoto sanitário, reator anaeróbio operado em batelada seqüencial, suporte inerte, PCR/DGGE.

\begin{abstract}
The performances of two anaerobic sequencing batch reactors $\left(1.2 \mathrm{~m}^{3}\right)$ containing biomass immobilized in inert support and as granular sludge in the treatment of domestic sewage from the Campus of São Carlos-University of São Paulo were evaluated. The experimental phase lasted seventy days. During this period, the reactors presented quite similar performances in respect to COD and total suspended solids removal, achieving average efficiencies of approximately 60\% and 75\%, respectively. The analysis using molecular biology techniques on biomass samples taken at $35^{\text {th }}$ and $70^{\text {th }}$ showed differences in the bacterial community in the reactors indicating that the type of biomass immobilization selected the populations differently. A higher similarity was found for the Archaea domain probably because these microorganisms utilize specific substrates formed at the end of the anaerobic process.
\end{abstract}

KEYWORDS: Batch reactor, anaerobic treatment, domestic sewage, $P C R / D G G E$.

\section{INTRODUÇÃO}

Como alternativa aos reatores anaeróbios de fluxo contínuo, o reator anaeróbio operado em batelada seqüencial vem recebendo atenção maior nos últimos anos, com pesquisas que visam sua aplicação prática no tratamento de águas residuárias em geral. O desenvolvimento desse reator anaeróbio é recente e os resultados obtidos indicam potencialidade destas unidades serem 
utilizadas no tratamento anaeróbio de diversos substratos. Sua aplicação em maior escala no tratamento de águas residuárias pode ser justificada em casos especiais. Por exemplo, para o tratamento de esgotos sanitários de pequenas comunidades, indústrias que lançam efluentes líquidos de forma descontínua, ou efluentes de atividades sazonais.

O reator anaeróbio operado em batelada seqüencial (ASBR-"Anaerobic Sequencing Batch Reactor"- Dague et al,1992), surgiu como alternativa ao Processo Anaeróbio de Contato, já que, nesse sistema com mistura completa e fluxo contínuo, o biogás gerado provoca a flotação de parte do lodo contido no reator, implicando na utilização de decantador para possibilitar o retorno de lodo biológico descartado, juntamente, com o efluente. Tal reator de fluxo intermitente vem sendo estudado de forma efetiva, desde 1991, por grupos de pesquisadores da Universidade Estadual de Iowa (EUA) e da Universidade de Ottawa (Canadá) em escala de laboratório e, no Brasil, por grupos da Escola de Engenharia de São Carlos (EESC/USP), da Escola de Engenharia do Instituto Mauá de Tecnologia (EEM/IMT) e do Instituto de Pesquisas Hidráulicas da Universidade Federal do Rio Grande do Sul (IPH/UFRGS). Nessas instituiçôes brasileiras, os projetos de pesquisa têm enfoque no estudo de otimização do reator tipo ASBR e de novas propostas de configuraçôes de reatores, para que a aplicação do sistema operado em batelada seqüencial em escala plena se torne viável.

No ASBR, o tratamento biológico é realizado em uma única unidade por meio de seqüência operacional (ciclo) composta de quatro etapas distintas: (i) alimentação: entrada do substrato, (ii) reação: contato, por meio de agitação, entre substrato e a biomassa presente para conversão da matéria orgânica a metano e dióxido de carbono, (iii) sedimentação: separação da fase sólida (lodo biológico), sendo esta extremamente dependente da formação de lodo auto-imobilizado ou granular com boas características de sedimentação e (iv) descarte: saída do líquido tratado e clarificado. Em alguns casos, após a etapa de descarte, faz-se necessário incluir a etapa de (v) repouso para flexibilidade de operação de vários reatores simultaneamente. Os ciclos podem ser repetidos indefinidamente, desde que a duração do ciclo total forneça tempo necessário para realização da seqüência de operação.

$\mathrm{Na}$ etapa de reação, que é a principal delas, a agitação pode ser contínua ou in- termitente. A agitação pode ser promovida por agitadores mecânicos (Timur \& Özturk, 1999; Cybis \& Pescador, 2000), recirculação interna de líquido (Brito et al, 1997; Cuevas-Rodrigues et al, 1998) ou borbulhamento do próprio biogás gerado no sistema (Dague et al, 1992; Sung \& Dague, 1995). O descarte de líquido tratado pode se dar por meio de tomada localizada em um nível pré-determinado, com vazão regulada (válvula ou bomba), sendo o tempo requerido governado pelo volume total a ser descartado durante cada ciclo.

A proposição de novas configuraçōes de reatores visa resolver os problemas operacionais identificados nos reatores anaeróbios operados em batelada seqüencial convencional (ASBR), ligados principalmente à perda de material biológico com o efluente. Uma alternativa que parece promissora é a utilização de biomassa imobilizada em meio suporte inerte. $\mathrm{O}$ uso de suporte inerte resulta em maior retenção de sólidos biológicos no sistema, pois dificulta o arraste observado nos reatores ASBR. Conseqüentemente, a fase de sedimentação pode ser eliminada, possibilitando a redução do tempo total de ciclo. Nesse contexto, Ratusznei et al (2000) propuseram nova configuração de reator anaeróbio operado em batelada seqüencial contendo biomassa imobilizada utilizando cubos de espuma de poliuretano como material suporte, sendo denominado de ASBBR - "Anaerobic Sequencing Batch Biofilm Reactor".

Esta nova configuração de reator (ASBBR) e os vários problemas decorrentes de seu emprego devem ser investigados para ampla viabilidade de aplicação no tratamento de águas residuárias. Neste sentido, este estudo possibilitou enfocar a potencialidade de utilização dessa configuração de reator com biomassa imobilizada em suporte inerte (ASBBR), bem como a comparação dos desempenhos das duas configurações ASBBR e ASBR convencional no tratamento de esgoto sanitário. Adicionalmente, as comunidades microbianas presentes nos dois sistemas foram avaliadas e comparadas em relação ao domínio Bacteria e Archaea, por meio da técnica da reação em cadeia de polimerase (PCR), seguida da eletroforese em gel com gradiente desnaturante (DGGE).

\section{MATERIAL E MÉTODOS}

Existem poucos dados específicos, na literatura, para projeto de reatores anaeróbios operados em bateladas seqüenciais. Por esse motivo, tornou-se necessário adotar alguns parâmetros construtivos para viabilizar o projeto das unidades em escala piloto, já que, na maioria, os parâmetros relatados na literatura referem-se a reatores em escala de bancada tratando substratos simples e que praticamente não retratam a realidade de sistemas em maior escala.

Os reatores anaeróbios do tipo ASBR e ASBBR foram concebidos para tratamento de $4 \mathrm{~m}^{3} \cdot \mathrm{d}^{-1}$ de esgotos sanitários provenientes do Campus da Universidade de São Paulo (São Carlos-SP). As unidades foram projetadas, individualmente, para o tratamento de $2 \mathrm{~m}^{3} \cdot \mathrm{d}^{-1}$ e apresentavam concepçôes diferentes no que se refere à forma de retenção de biomassa (suporte inerte e biomassa granular).

No ASBR destinou-se $1 / 3$ do volume total $\left(\mathrm{V}_{\mathrm{T}}\right)$ como volume para acumulação de lodo ou retenção da biomassa na forma auto-imobilizada ou granular. $\mathrm{O}$ volume reservado para acumulação de biogás foi adotado como sendo, aproximadamente, $10 \%$ do volume total. Desse modo, o projeto dos reatores ASBR baseou-se nas considerações apresentadas nas equaçōes 1 e 2 relacionadas com a Figura 1. O esquema do ASBR projetado está apresentado na Figura 2, conforme suas dimensões e características construtivas.

$$
\begin{aligned}
& V_{T}=V_{R}+V_{L}+V_{G} \\
& V_{U}=V_{R}+V_{L}
\end{aligned}
$$

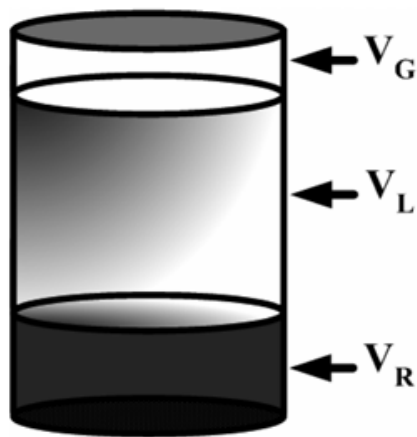

$\mathrm{V}_{\mathrm{T}}=$ volume total

$\mathrm{V}_{\mathrm{U}}=$ volume útil

$\mathrm{V}_{\mathrm{R}}=$ volume destinado à retenção de biomassa (lodo)

$\mathrm{V}_{\mathrm{L}}=$ volume liquido removível (volume a ser tratado)

$\mathrm{V}_{\mathrm{G}}=$ volume destinado à acumulação de biogás

Figura I- Representação esquemática dos volumes destinados para a fase sólida (lodo), líquida e gasosa no reator ASBR 
Material: Polietileno

$\mathrm{V}_{\mathrm{T}}: 1,20 \mathrm{~m}^{3}$

$\mathrm{V}_{\mathrm{U}}: 1,06 \mathrm{~m}^{3}$

$\mathrm{V}_{\mathrm{R}}: 0,41 \mathrm{~m}^{3}$

$\mathrm{V}_{\mathrm{L}}: 0,65 \mathrm{~m}^{3}$

$\mathrm{V}_{\mathrm{G}}: 0,14 \mathrm{~m}^{3}$

Altura: $1,5 \mathrm{~m}$

Diâmetro: $1,0 \mathrm{~m}$

Agitação: Mecânica (30 rpm)

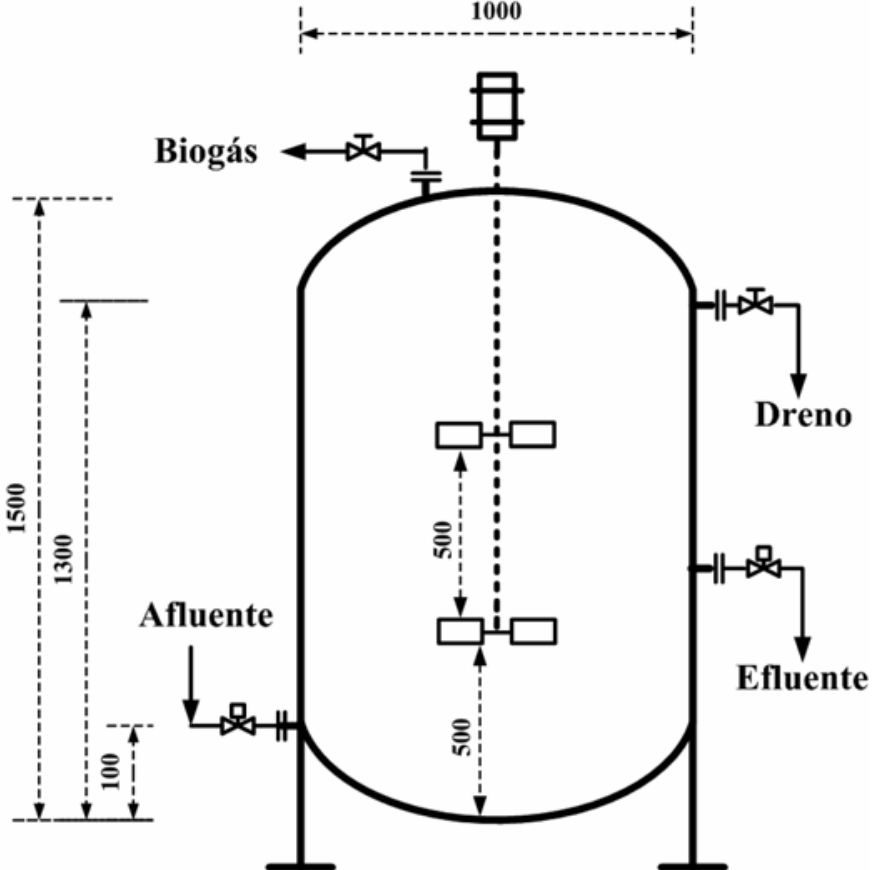

Figura 2 - Reator ASBR com agitação mecânica (medidas em mm)

A concepção da configuração ASBBR, em escala piloto, baseou-se no trabalho de Ratusznei et al (2000). Nesse trabalho, o reator ASBBR (escala de laboratório) tratou esgoto sanitário sintético utilizando como suporte inerte espuma de poliuretano e atingiu eficiência média de remoção de $86 \%$ em termos de matéria orgânica. Este reator ASBBR tem como peculiaridade manter as biopartículas (cubos de espuma de poliuretano) confinadas em uma espécie de "cesto cilíndrico" ao redor do eixo do agitador.

Neste caso, para tratar o mesmo volume de líquido a cada ciclo de $0,65 \mathrm{~m}^{3}\left(\mathrm{~V}_{\mathrm{L}}\right)$ e ter volume útil $\left(1,04 \mathrm{~m}^{3}\right)$ semelhante ao do reator $\operatorname{ASBR}\left(1,06 \mathrm{~m}^{3}\right)$, adequouse o projeto do reator ASBBR manipulando-se a variável porosidade de leito, a qual resultou em 0,4 ou $40 \%$. A partir desta variável adotou-se o volume no fundo do reator para eventual descarte de lodo não imobilizado de $7 \%$ do volume total, sendo semelhante valor percentual considerado para o volume de acumulação de biogás. No reator ASBBR, foram adotados os valores resultantes da aplicação das equações 3 , 4 e 5 relacionadas com a Figura 3. O reator ASBBR dimensionado está apresentado na Figura 4.

$\mathrm{V}_{\mathrm{T}}=\mathrm{V}_{\mathrm{A}}+\mathrm{V}_{\mathrm{D}}+\mathrm{V}_{\mathrm{G}}+\mathrm{V}_{\mathrm{S}}$

$\mathrm{V}_{\mathrm{U}}=\mathrm{V}_{\mathrm{A}}+\mathrm{V}_{\mathrm{S}}$

$\mathrm{V}_{\mathrm{L}}=\mathrm{V}_{\mathrm{A}}+\mathrm{V}_{\mathrm{S}} * \varepsilon$

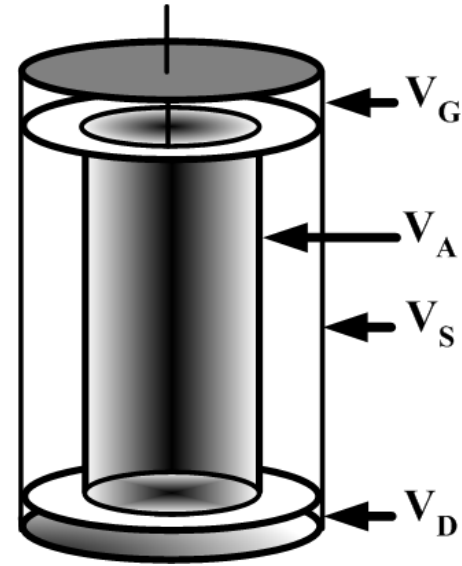

Figura 3 - Representação esquemática dos volumes destinados para a acomodação do suporte inerte e das fases sólida (lodo-descarte eventual), líquida e gasosa no reator ASBBR

$$
\begin{gathered}
\mathrm{V}_{\mathrm{A}}=\text { volume destinado para sistema de agitação } \\
\mathrm{V}_{\mathrm{S}}=\text { volume para acomodação do suporte inerte } \\
\mathrm{V}_{\mathrm{D}}=\text { volume para descarte de lodo } \\
\varepsilon=\text { porosidade do leito de espuma }
\end{gathered}
$$

No ASBBR, em escala piloto, o suporte inerte ficou confinado no interior do cesto cilíndrico (fechado), confeccionado de tela perfurada (Inox 316 e $\phi_{\text {orificio }}: 15 \mathrm{~mm}$ ) alocado ao redor do eixo do agitador. Os suportes inertes para imobilização da biomassa foram cubos (50 $\mathrm{mm}$ de lado) de espuma de poliuretano (densidade aparente: $23 \mathrm{~kg} \cdot \mathrm{m}^{-3}$ ).
O tempo de ciclo total foi de 8 horas, baseado no trabalho de Ratusznei et al (2000). A adoção desse tempo de ciclo total implicou na realização de três ciclos completos por dia, sendo cada ciclo correspondente aos tempos de enchimento, reação, sedimentação, descarga e repouso para o reator ASBR. No caso do ASBBR, foi dispensada a fase de sedimentação por 
se tratar de reator contendo biomassa imobilizada em meio suporte. Na Tabela 1, visualizam-se os tempos das etapas envolvidas na execução do ciclo total dos reatores.
Tabela I - Tempos das etapas para o ciclo total (8 horas) de operação dos reatores

\begin{tabular}{cc}
\hline ASBR & ASBBR \\
\hline Enchimento: $2 \mathrm{~h}$ & Enchimento: $2 \mathrm{~h}$ \\
Reação com agitação: $3 \mathrm{~h}$ & Reação com agitação: $5 \mathrm{~h}$ \\
Sedimentação: $2 \mathrm{~h}$ & Não há fase de Sedimentação \\
Descarga: $0,5 \mathrm{~h}$ & Descarga: $0,5 \mathrm{~h}$ \\
Repouso: $0,5 \mathrm{~h}$ & Repouso: $0,5 \mathrm{~h}$ \\
\hline
\end{tabular}

Material: Polietileno

$\mathrm{V}_{\mathrm{T}}: 1,20 \mathrm{~m}^{3}$

$\mathrm{V}_{\mathrm{U}}: 1,04 \mathrm{~m}^{3}$

$\mathrm{V}_{\mathrm{A}}: 0,41 \mathrm{~m}^{3}$

$V_{S}: 0,62 \mathrm{~m}^{3}$

$V_{E}=V_{S} \cdot(1-\varepsilon)=0,37 \mathrm{~m}^{3}$

$\mathrm{V}_{\mathrm{E}}=$ volume de cubos de espuma

$V_{G}: 0,085 \mathrm{~m}^{3}$

$V_{D}: 0,085 \mathrm{~m}^{3}$

Altura: $1,5 \mathrm{~m}$

Diâmetro: $1,0 \mathrm{~m}$

Agitação: Mecânica (30 rpm)

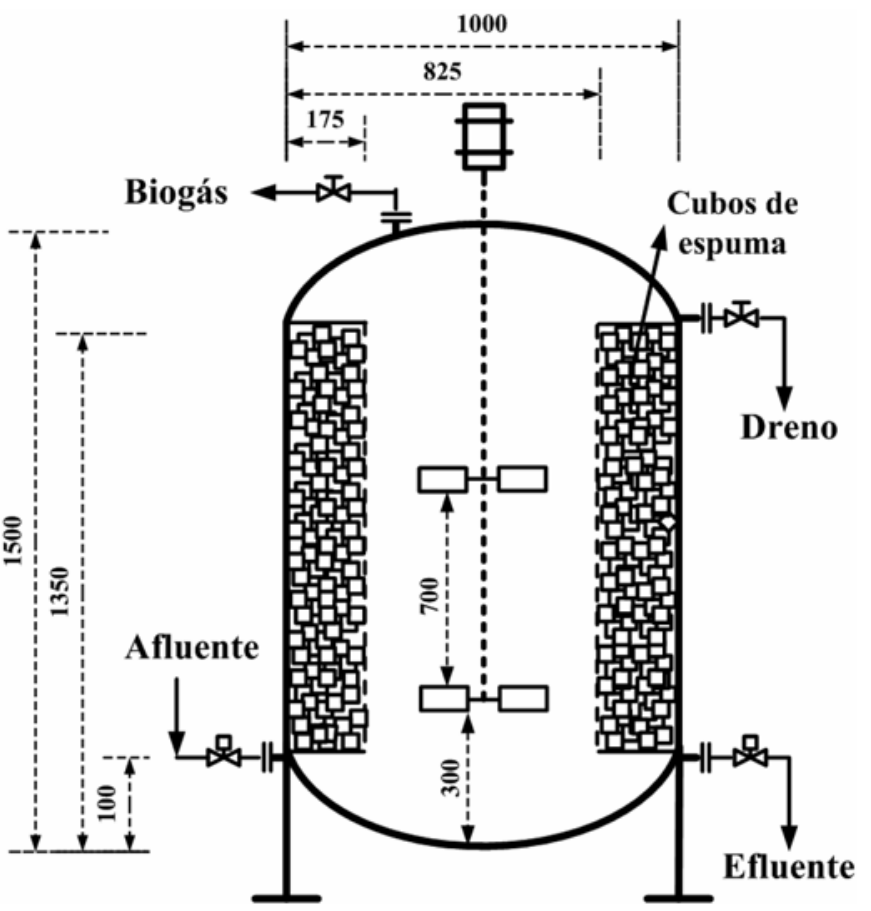

Figura 4 - Reator ASBBR com agitação mecânica (medidas em mm)

Em conseqüência da complexidade da operação simultânea, tornou-se impossível operar manualmente as unidades. Portanto, o sistema foi automatizado por controle temporal supervisionado por microcomputador. As açôes seqüenciais das etapas (enchimento, reação com agitação, sedimentação, descarga e repouso) a cada ciclo total nos reatores foram agendadas na forma temporal (minutos) por meio de software específico desenvolvido em DELPHI 3 operando em ambiente MS-Windows. Essas açôes seqüenciais de acionamentos envolveram abertura/fechamento de válvulas automatizadas instaladas nas redes de alimentação e descarte (etapas de alimentação e descarte), bem como os agitadores mecânicos (etapa de reação). A velocidade de rotação dos agitadores foi controlada por meio de regulador eletrônico PWM, sendo efetivamente monitorados utilizando tacômetros acoplados aos eixos de cada reator.

Nos reatores foram utilizados, individualmente, dois impelidores tipos turbina (seis pás planas), confeccionados em aço inox 316, cujas características geométricas foram especificadas conforme Metcalf \& Eddy (1991) (Figura 5a). Os sistemas de agitação (moto-redutor, impelidores e eixo) podem ser vistos nas Figuras 5 b e 5 c. A potência instalada nos reatores foi de $1 / 3 \mathrm{CV}$ dada pelo motoredutor acoplado.

Os reatores ASBR e ASBBR foram instalados em sala construída na Estação de Tratamento de Esgoto da USP de São Carlos e mantidos em temperatura ambiente $\left(29 \pm 5^{\circ} \mathrm{C}\right)$ durante a fase experimental (70 dias). O monitoramento das unidades envolveu análises físico-químicas do afluente e efluente como demanda química do oxigênio (DQO) bruta e fil- trada (membrana 1,2 $\mu \mathrm{m}$ ), pH, sólidos suspensos totais (SST) e sólidos suspensos voláteis (SSV) conforme metodologias descritas no Standard Methods for Examination of Water and Wastewater (1995). A concentração de ácidos voláteis totais (AVT) em termos de ácido acético (Hac) e alcalinidade a bicarbonato $\left(\mathrm{CaCO}_{3}\right)$ foram analisadas de acordo com método descrito por Dilallo \& Albertson (1961) e modificado por Ripley et al (1986).

A amostragem simples ou pontual do afluente (esgoto sanitário) era realizada durante a fase de alimentação dos reatores e feita diretamente na tubulação de recalque de bomba centrífuga (Jacuzzimodelo 5JL15) utilizada no enchimento das unidades. No efluente, a amostragem pontual de ambos sistemas era efetuada de forma simultânea ao final do ciclo de 8 horas. A composição do biogás produ- 


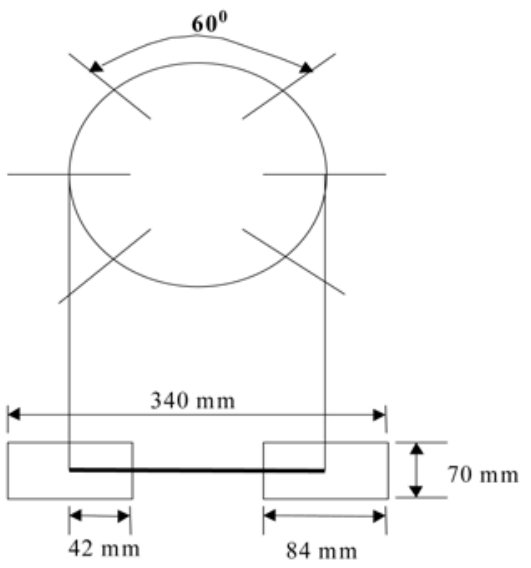

(a)

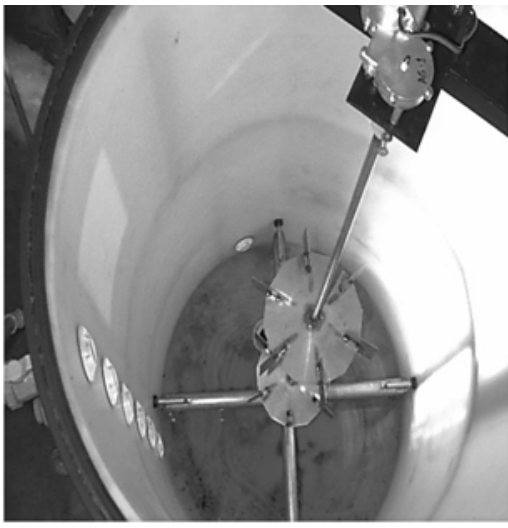

(b)

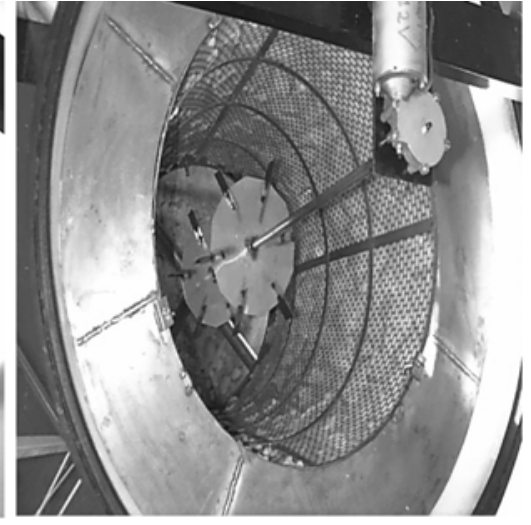

(c)

Figura 5 - Características geométricas dos impelidores (a) e sistema de agitação acoplado nos reatores ASBR (b) e ASBBR (c)

zido pelo processo de degradação anaeróbia era analisada por meio de cromatografia gasosa (Cromatógrafo Gow-Mac com detector de condutividade térmica e hidrogênio como gás de arraste) e a amostra coletada com ampola de vidro $(300 \mathrm{ml})$ antes da etapa de descarga dos reatores. Tais amostragens eram efetuadas semanalmente ( 2 coletas) perfazendo no total 20 coletas. Somente as análises de SST e SSV eram realizadas com freqüência de apenas uma coleta semanal (11 coletas).

Os reatores ASBBR e ASBR foram a princípio inoculados com biomassa granular ou lodo granular (anaeróbio) proveniente de reator UASB usado no tratamento de água residuária de abatedouro de aves (Avícola Dacar - Tiête - SP). A quantificação da biomassa presente no inóculo em termos de sólidos totais (ST) e sólidos voláteis (SV) baseou-se na metodologia citada no Standard Methods for Examination of Water and Wastewater (1995). Essa mesma metodologia de quantificação foi realizada no $35^{\circ}$ e $70^{\circ}$ dia de operação no reator ASBR. No caso do ASBBR, com meio suporte, a metodologia descrita por Ribeiro et al (2005) foi utilizada para a quantificação da biomassa na espuma, também, no $35^{\circ} \mathrm{e}$ $70^{\circ}$ dias de operação.

O lodo granular inoculado apresentava concentração inicial em termos de sólidos totais (ST) e sólidos voláteis (SV) de 64,1 kgST.m ${ }^{-3}$ e 52,8 kgSV.m ${ }^{-3}$, respectivamente. Como o reator ASBR recebeu volume aproximado de $0,40 \mathrm{~m}^{3}$ de biomassa granular e o reator tem volume total de $1,2 \mathrm{~m}^{3}$, as concentrações em termos de SV e ST na partida foram de
21,3 kgST.m ${ }^{-3}$ e 17,6 kgSV.m ${ }^{-3}$, respectivamente. Para o reator ASBBR o lodo granular foi macerado e diluído em água (60l-lodo + $60 l$-água) com intuito de viabilizar o processo de inoculação dos cubos de espuma de poluiretano. Esgoto sanitário foi admitido para completar o volume da unidade e a agitação mecânica mantida durante 10 dias. Ao final desse período, os dados iniciais de concentração de biomassa na espuma de poliu retano foram de $0,28 \mathrm{kgST}$. $\mathrm{kg}$ espuma ${ }^{-1}$ e $0,21 \mathrm{kgSV} \cdot \mathrm{kg}_{\text {espuma }}{ }^{-1}$.

A partir do período inicial de 10 dias, em função do processo de inoculação do ASBBR, é que efetivamente iniciou-se a operação e o monitoramento de ambos os reatores no tratamento de esgoto sanitário para efeito de comparação de desempenho.

\section{Análise microbiológica}

A estrutura microbiana foi analisada por meio de técnicas de biologia molecular (PCR e DGGE) e as amostras utilizadas nessa análise foram coletadas do volume destinado ao acúmulo de lodo $\left(V_{R}\right)$ no reator ASBR (1 l) e da espuma de poliuretano do ASBBR (1 cubo de espuma) no $35^{\circ}$ e $70^{\circ}$ dias de operação.

\section{- Extração do DNA e amplificação por PCR}

A extração do DNAr foi realizada conforme Melvin \& Hobson (1994). Na purificação do DNA utilizou-se o Kit Wizard DNA Clean-Up System (Promega). Na reação de polimerização em cadeia (PCR) foi utilizado o "primer forward" 968FGC clamp e o "reverse" 1392 R (Nielsen et al, 1999) para o Domínio Bactéria e o "primer forward" 1100 FGC clamp e o "reverse" $1400 \mathrm{R}$ (Kudo et al, 1997) para o Domínio Archaea. Na reação de amplificação do fragmento do DNAr 16S foi utilizada as soluçôes: "Taq DNA polymerase" $(5 \mathrm{U} / \mathrm{ml}) ; 10 \times$ Tampão PCR (com 1,5 $\mathrm{mM} \mathrm{MgCl}_{2}$ ); dNTP (2mMcada); 20 pmol do "primer forward" e do "primer reverse"; 50-100ng de DNA ("template"). Utilizou-se o termociclador "Gene Amp. PCR System 2400" (Perkin-Elmer Cetus, Norwalk, Conn). O procedimento utilizado na amplificação do fragmento de DNAr 16S para o Domínio Bactéria foi realizado segundo Nielsen et al (1999), enquanto para o Domínio Archaea foi o método descrito por Kudo et al (1997).

- Eletroforese em gel de gradiente desnaturante (DGGE)

A solução do gel gradiente desnaturante ( $40 \%$ de gel acrilamida; solução 50 x TAE; formamida e uréia) foi usada nas concentrações de $40 \%$ - $60 \%$ e 35\% - 55\% para o Domínio Bactéria e Archaea respectivamente (Muyzer et al, 1993). Na "corrida" manteve-se a temperatura constante de $60^{\circ} \mathrm{C}$, a voltagem de $130 \mathrm{~V}$ e o tempo de aproximadamente 390 minutos. A solução fluorescente utilizada foi a Vistra green (diluída 10.000 vezes). Utilizou-se para leitura dos padrôes de bandas obtidas no DGGE, Eagle Eye TM III (Stratagene),

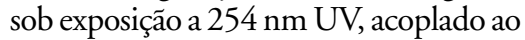
computador (Software Eagle Sight). 
- Equação para interpretação das bandas do DGGE

Na comparação das bandas padrão de DGGE utilizou-se a equação descrita por Gillan et al. (1998). Esta equação (6) calcula o coeficiente de similaridade entre duas amostras e considera o número de bandas do DGGE de cada amostra e o número de bandas em comum presentes nessas amostras. Para dois perfis idênticos de DGGE, o valor do coeficiente de similaridade é de $100 \%$, e para perfis totalmente diferentes o valor é de $0 \%$. Esta equação não considera a intensidade das bandas de DGGE como fator variável. A equação para o cálculo do coeficiente de similaridade (Cs) está descrita a seguir:

$$
C s=\frac{2 J}{(a+b)} \times 100
$$

Onde:

a - número de bandas do DGGE na amostra 1,

b - número de bandas do DGGE na amostra 2,

J - número de bandas do DGGE comuns.

\section{RESULTADOS E DISCUSSÃO}

\section{- Reator ASBBR}

A partir do $10^{\circ}$ dia de operação do ASBBR, a presença de metano foi evidenciada no biogás, indicando efetivamente o inicio do tratamento biológico anaeróbio (Figura 6a). O reator atingiu durante os primeiros 10 dias de operação valores médios de remoção de $\mathrm{DQO}_{\text {Bruta }}$ e $\mathrm{DQO}_{\text {Filtrad }}$ de $65 \%$ e $73 \%$, respectivamente. As concentrações médias de DQO no efluente, no mesmo período, foram de $210 \pm 12 \mathrm{mg}^{-1} \mathrm{l}^{-1}\left(\mathrm{DQO}_{\text {Bruta }}\right) \mathrm{e}$ $160 \pm 17 \mathrm{mg}^{-1} \mathrm{l}^{-1}$ (DQO $\mathrm{Filtrada}$ ) (Figura 6b). Tais valores de eficiência não estão diretamente relacionados ao tratamento biológico, mas sim ao processo de retenção física de sólidos na espuma de poliuretano, como pôde ser notado pela baixa concentração de DQO particulada no efluente (Figura $6 b$ ).

Neste caso, o processo de inoculação utilizado não viabilizou por completo a colonização microbiana do material suporte. Provavelmente, maior quantidade de lodo do inóculo seria necessária para melhorar a eficácia da inoculação, a fim de propiciar o inicio do tratamento biológico no $1^{\circ}$ dia de operação. Portanto, a formação específica de microbiota anaeróbia no ASBBR ficou dependente do esgoto sanitário admitido no reator a cada ciclo.

Tal afirmação pôde ser confirmada, ao longo da operação do ASBBR, devido ao aumento da quantidade de biomassa aderida na espuma de poliuretano em termos de concentração de sólidos totais e voláteis. No $1^{\circ}$ dia de operação, após o processo de inoculação, os valores eram de $0,28 \mathrm{kgST}$. $\mathrm{kg}$ espuma ${ }^{-1}$ e $0,21 \mathrm{kgSV} . \mathrm{kg}$ espuma ${ }^{-1}$, sendo que, ao final da fase experimental ( $\left.70^{\circ} \mathrm{dia}\right)$, alcançaram-se as concentrações de 0,62 kgST.kgespuma ${ }^{-1}$ e 0,45 kgSV.kgespuma $^{-1}$ (Figura 6 c). Provavelmente, a estabilidade de operação (equilíbrio dinâmico aparente) no ASBBR possa ser alcançada em curto espaço de tempo, mesmo que a inoculação seja deficiente (10 a 20 dias).

Ao final de 70 dias de operação, o efluente do reator ASBBR apresentou valores médios em termos de $\mathrm{DQO}_{\text {Bruta }} \mathrm{e}$ $\mathrm{DQO}_{\text {Filtrada }}$ de $215 \pm 50 \mathrm{mg}^{-1} \mathrm{l}^{-1}$ (mín: $148 \mathrm{mg}^{-1}$ ) e $127 \pm 28 \mathrm{mg}^{-1} \mathrm{l}^{-1}$ (mín: $82 \mathrm{mg} . \mathrm{l}^{-1}$ ), respectivamente. Em termos de sólidos suspensos totais (SST), o valor mé-dio obtido foi de $62 \pm 29 \mathrm{mgSST}^{-1}{ }^{-1}$ (mín: $36 \mathrm{mgSST}^{-1}{ }^{-1}$ ) e para sólidos suspensos voláteis (SSV) de $54 \pm 24 \mathrm{mgSSV} \cdot \mathrm{l}^{-1}$ (mín: $33 \mathrm{mgSSV} \cdot \mathrm{l}^{-1}$ ). A eficiência média de remoção de SST atingiu $75 \%$, enquanto a remoção de SSV chegou a $73 \%$ (Figura 6d). No mesmo período, a concentração média de ácidos voláteis totais (AVT) no afluente do reator de $68 \pm 13$ mgHac. $\mathrm{l}^{-1}$ (máx.: $91 \mathrm{mgHac} . \mathrm{l}^{-1}$ ) e no efluente de $49 \pm 12 \mathrm{mgHac}^{-1}$

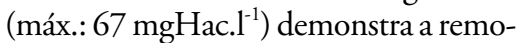
ção de AVT. A alcalinidade a bicarbonato no efluente do reator $\left(118 \pm 20 \mathrm{mgCaCO}{ }_{3} .^{-1}\right)$ apresentou concentração média superior ao afluente $\left(84 \pm 16 \mathrm{mgCaCO} \cdot \mathrm{l}^{-1}\right)$. Portanto, ocorreu a geração de alcalinidade bicarbonato evidenciada pela maior concentração no efluente comprovando a remoção de AVT. Portanto, não houve desbalanceamento entre as fases metanogênica e acidogênica.

\section{- Reator ASBR}

No reator ASBR, a concentração de metano presente no biogás (Figura 7a) foi o indicativo do início do tratamento biológico do esgoto sanitário. Esse fato ocorrido no $1^{\circ}$ dia de operação está relacionado, logicamente, à presença de lodo biológico granular anaeróbio. No caso específico dos reatores ASBR, a presença de biomassa na forma de grânulos é essencial no desempenho e na estabilidade da operação, devido às suas excelentes características de sedimentação.
Ao longo da fase experimental, houve perda de lodo biológico no ASBR, provavelmente relacionada com a seleção da própria biomassa granular com melhor característica de sedimentaçãoo (Figura 7c), sendo que a estabilidade de operação (equilíbrio dinâmico aparente), com eficiência de remoção de DQO satisfatória, pode ser alcançada após 20 dias de operação (Figura $7 \mathrm{~b}$ ). Os dados de concentração de lodo, expressos como sólidos totais (ST) e voláteis (SV), confirmam a perda de lodo. Inicialmente, o lodo de inóculo aplicado no ASBR apresentava concentrações de $64,1 \mathrm{gST.} .^{-1}$ e 52,8 $\mathrm{gSV} .1^{-1}$, sendo que após 70 dias, os valores decresceram para $18,1 \mathrm{gST}^{-1}{ }^{-1}$ e $15,3 \mathrm{gSV} . \mathrm{l}^{-1}$. Do ponto de vista operacional tal perda foi benéfica ao ASBR, em função da retirada de biomassa granular que apresentava baixa sedimentabilidade reduzindo a concentração de sólidos suspensos (Figura 7d) e resultando em menor presença de DQO particulada no efluente, após 20 dias de operação (Figura $7 \mathrm{~b}$ ).

Os valores médios no efluente (70 dias) em termos de $\mathrm{DQO}_{\text {Bruta }}$ e DQO $_{\text {Filtrad }}$ noASBR foram de $215 \pm 50 \mathrm{mg}^{-1}$ (mín: 134 mg.l ${ }^{-1}$ ) e $120 \pm 23$ mg..$^{-1}$ (mín: $68 \mathrm{mg}^{-\mathrm{l}^{-1}}$ ), respectivamente. As eficiências médias de remoção de DQO nas amostras brutas e filtradas atingiram valores de 60\% (máx: 75\%) e 78\% (máx: 89\%), respectivamente. Em termos de eficiência média de remoção de SST e SSV no ASBR obtiveram-se valores de $79 \%$. No efluente, as concentrações médias foram de $53 \pm 12 \mathrm{mgSST}^{-1}$

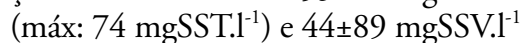
(máx: 63 mgSST. $\mathrm{l}^{-1}$ ) no ASBR2.

No mesmo período, as concentraçōes médias de AVT no afluente e no efluente do ASBR foram de $68 \pm 13 \mathrm{mgHac}^{-1}$ (máx: $91 \mathrm{mgHac}^{-1} \mathrm{l}^{-1}$ e e de $40 \pm 11 \mathrm{mgHac}^{-1}$ (máx: $58 \mathrm{mgHac}^{-1}{ }^{-1}$ ), respectivamente. Observou-se que houve geração de alcalinidade a bicarbonato durante $o$ processo de tratamento, sendo que o valor médio no afluente foi de $84 \pm 16 \mathrm{mgCaCO}_{3} \cdot \mathrm{l}^{-1}$, enquanto que, no efluente, foi de $133 \pm 24 \mathrm{mgCaCO} . \mathrm{l}^{-1}$. Portanto, deve-se ressaltar também que não ocorreu desbalanceamento entre as fases metanogênica e acidogênica no reator ASBR.

\section{- Análise final}

A partir dos resultados de monitoramento (Tabela 2) durante 70 dias de operação, observa-se a semelhança no desempenho dos reatores ASBR e ASBBR, 


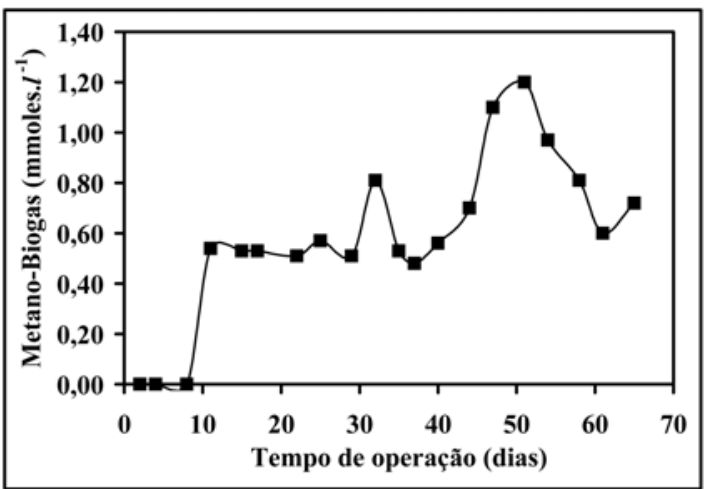

(a)

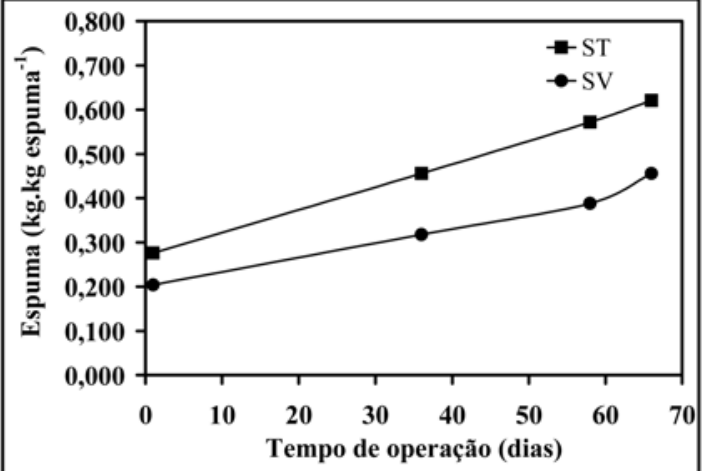

(c)

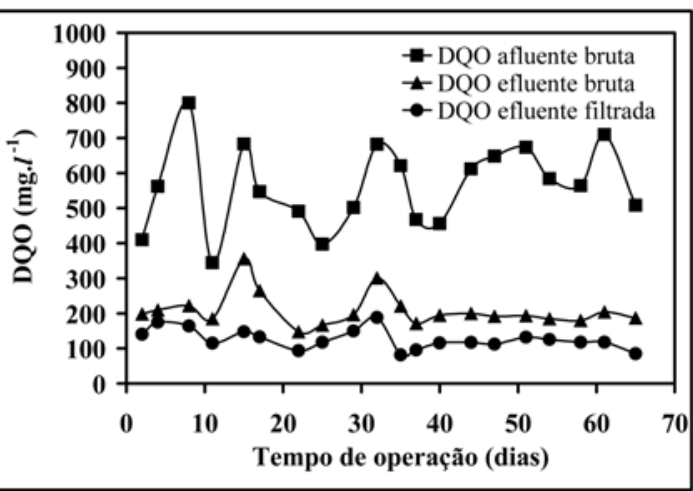

(b)

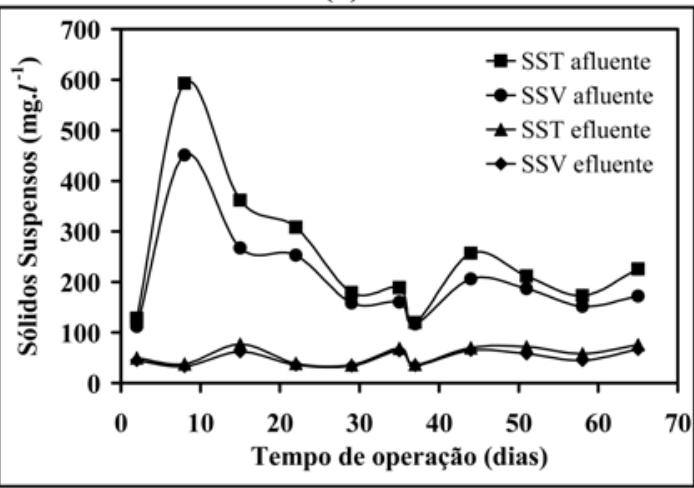

(d)

Figura 6 - Variação temporal no reator ASBBR da concentração de metano no biogás (a), DQO bruta e filtrada (b), ST e SV no meio suporte (c) e SST e SSV (d)

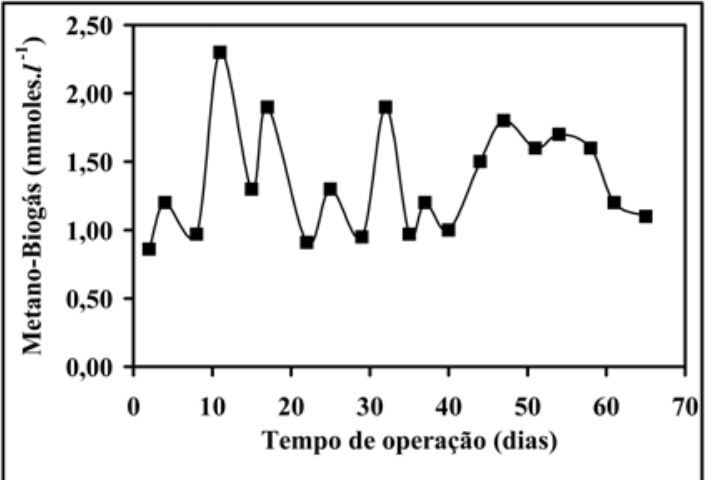

(a)

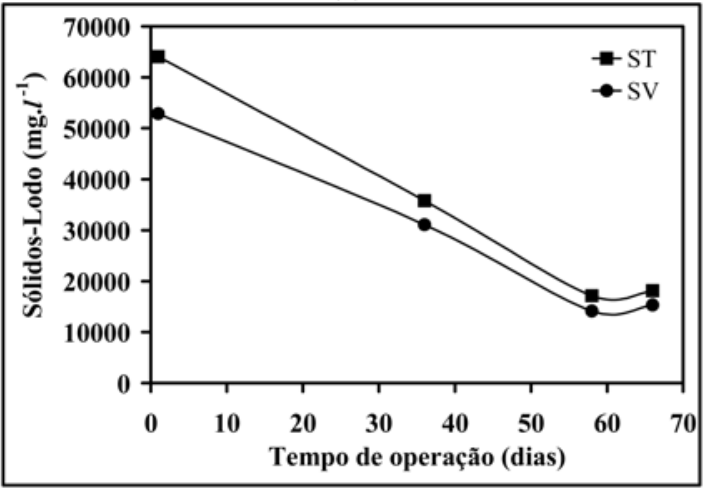

(c)

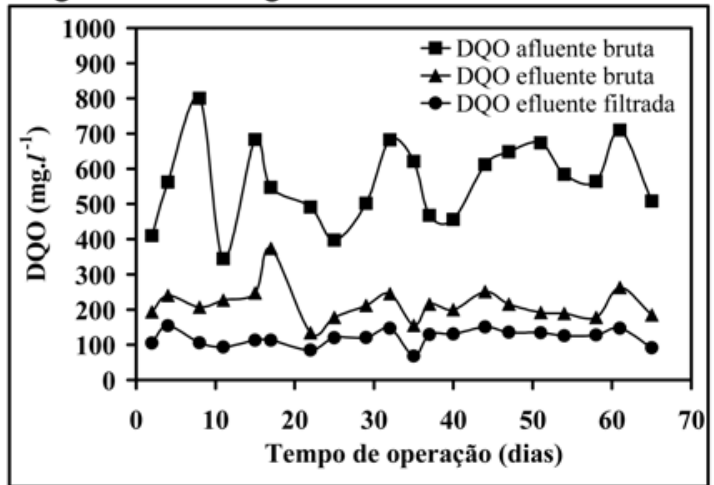

(b)

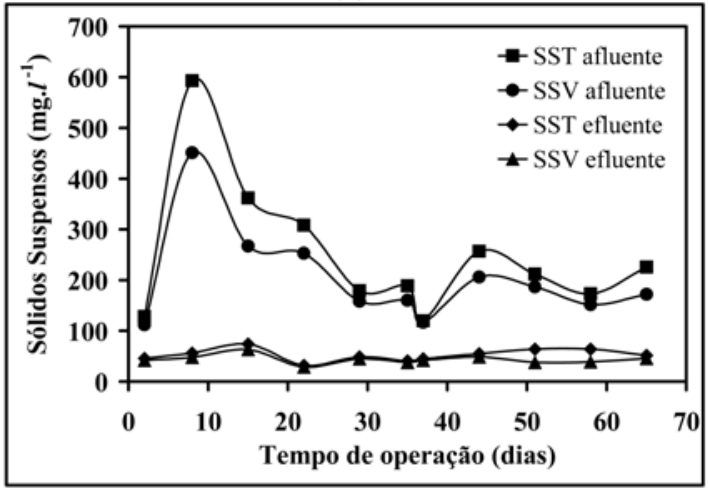

(d)

Figura 7 -Variação temporal no reator ASBR da concentração de metano no biogás (a), DQO bruta e filtrada (b), ST e SV (c) e SST e SSV (d) 
principalmente em termos de DQO no efluente. Como forma de comparação de desempenho das unidades em termos de $\mathrm{DQO}_{\text {Bruta }}$ eSST no efluente nesse período (concentraçóes médias) utilizou-se a ferramenta de análise de variância (ANOVA-fator único). Os resultados da utilização desta ferramenta estatística estão apresentados nas Tabelas 3 e 4.

Conforme observado na Tabela 3, o teste forneceu o menor valor $\operatorname{de} f_{\text {observado }}$ $(0,004)$ quando comparado com o $f_{\text {crírico }}$ $(4,10)$ obtido da distribuição de FisherSnedcor, com 1 e 32 graus de liberdade e considerando o nível de $5 \%$ de significância. Neste caso, pode-se concluir que as médias de DQO nas amostras brutas do efluente dos reatores foram similares. Em termos de SST (Tabela 4), o valor de $f_{\text {observado }}(1,9)$ também foi menor que o valor de $f_{\text {crítico }}(4,35)$ obtido da distribuição de Fisher-Snedcor, com 1 e 20 graus de liberdade e considerando nível de significância de 5\%. Tendo em vista que $f_{\text {observado }}<f_{\text {crítico }}$, é possível concluir que não existe diferença entre as médias de SST obtidas nos reatores. Ressalta-se que testes com a aplicação desta ferramenta estatística foram realizados, também, para as variáveis $\mathrm{DQO}_{\text {Filtrada }}$ e SSV e os resultados convergiram para valores de $f_{\text {observado }}<f_{\text {crítico }}$. Desta forma, considera-se que houve similaridade de desempenho nos reatores ASBR e ASBBR.

\section{- Estrutura microbiana}

$\mathrm{Na}$ avaliação da estrutura da comunidade microbiana para o domínio Bactéria (Figura 8), observou-se pequenas alteraçōes na diversidade populacional nas amostragens temporais, ou seja, nas amostras relativas ao $35^{\circ}$ e $70^{\circ}$ dias de operação nas duas diferentes configurações de reatores anaeróbios. $\mathrm{O}$ resultado do coeficiente de similaridade (Cs) do ASBR foi de $87 \%$ para as amostras $\left(35^{\circ} \mathrm{e}\right.$ $70^{\circ}$ dias), enquanto para o ASBBR de $81 \%$, o que sugere a presença e manutenção da maioria das populaçôes no período de 35 dias.

Pela comparação da estrutura da comunidade bacteriana (Figura 8), entre os dois reatores, pode-se verificar diferenças relativas à diversidade populacional, sendo essa diversidade maior no ASBBR. Tais diferenças estão diretamente relacionadas com a perda e a seleção do lodo granular ocorridas no ASBR, bem como a forma de imobilização da biomassa utilizada no ASBBR (espuma de poliuretano). Os diferentes resultados obtidos

Tabela 2 - Monitoramento do ASBR e ASBBR durante 70 dias de operação

\begin{tabular}{|c|c|c|c|}
\hline Parâmetro & Afluente & ASBBR & ASBR \\
\hline Carga orgânica aplicada (KgCOD.m $\left.{ }^{3} \cdot \mathrm{d}^{-1}\right)$ & $0,6-1,2$ & Efluente & Efluente \\
\hline $\mathrm{DQO}_{\text {Bruta }}\left(\mathrm{mg} \cdot \mathrm{l}^{-1}\right)$ & $\begin{array}{c}563 \pm 118 \\
(800-345)\end{array}$ & $\begin{array}{c}215 \pm 50 \\
(356-148)\end{array}$ & $\begin{array}{c}215 \pm 50 \\
(374-134)\end{array}$ \\
\hline $\mathrm{DQO}_{\text {Filtrada }}\left(\mathrm{mg} \cdot \mathrm{l}^{-1}\right)$ & $\begin{array}{c}190 \pm 37 \\
(244-120)\end{array}$ & $\begin{array}{c}127 \pm 28 \\
(188-22)\end{array}$ & $\begin{array}{c}120 \pm 23 \\
(154-68)\end{array}$ \\
\hline${ }^{*}$ Eficiência remoção ${ }_{\text {Bruta }}(\%)$ & - & $\begin{array}{c}61 \\
(72-46)\end{array}$ & $\begin{array}{c}60 \\
(75-32)\end{array}$ \\
\hline${ }^{*}$ Eficiência remoção ${ }_{\text {Filtrada }}(\%)$ & - & $\begin{array}{c}71 \\
(87-66)\end{array}$ & $\begin{array}{c}78 \\
(89-70)\end{array}$ \\
\hline Ácidos voláteis totais $\left(\mathrm{mgHac} . \mathrm{l}^{-1}\right)$ & $\begin{array}{l}68 \pm 13 \\
(91-36)\end{array}$ & $\begin{array}{l}49 \pm 12 \\
(67-27)\end{array}$ & $\begin{array}{c}40 \pm 11 \\
(58-19)\end{array}$ \\
\hline Alcalinidade a bicarbonato $\left(\mathrm{mgCaCO}_{3} \cdot \mathrm{l}^{-1}\right)$ & $\begin{array}{c}84 \pm 16 \\
(109-40)\end{array}$ & $\begin{array}{c}118 \pm 20 \\
(157-88)\end{array}$ & $\begin{array}{c}133 \pm 24 \\
(215-101)\end{array}$ \\
\hline $\mathrm{pH}$ & $7,2-6,6$ & $7,3-6,8$ & $7,3-6,8$ \\
\hline Sólidos S. totais (mg.l ${ }^{-1}$ ) & $\begin{array}{c}250 \pm 135 \\
(593-120)\end{array}$ & $\begin{array}{c}62 \pm 29 \\
(136-36)\end{array}$ & $\begin{array}{l}53 \pm 12 \\
(74-32)\end{array}$ \\
\hline Sólidos S. voláteis (mg..$^{-1}$ ) & $\begin{array}{c}203 \pm 96 \\
(451-112)\end{array}$ & $\begin{array}{c}54 \pm 24 \\
(116-33)\end{array}$ & $\begin{array}{c}44 \pm 09 \\
(116-33)\end{array}$ \\
\hline *Remoção sólidos S. totais (\%) & - & 75 & 79 \\
\hline *Remoção sólidos S.voláteis (\%) & - & 73 & 79 \\
\hline
\end{tabular}

()Valores máximo e mínimos

*Médias

Tabela 3 - Tabela de análise de variância (Anova-fator único) para DQO (amostras brutas)

\begin{tabular}{cccccc}
\hline $\begin{array}{c}\text { Fonte da } \\
\text { variação }\end{array}$ & $\begin{array}{c}\text { Soma dos } \\
\text { quadrados }\end{array}$ & $\begin{array}{c}\text { Graus de } \\
\text { liberdade }\end{array}$ & $\begin{array}{c}\text { Quadrado } \\
\text { médio }\end{array}$ & $f_{\text {observado }}$ & $f_{\text {crítico }}$ \\
\hline Entre grupos & 0,9 & 1 & 0,9 & 0,0004 & 4,10 \\
Dentro dos grupos & 95002 & 38 & 2500 & & \\
Total & 95003 & 39 & & & \\
\hline
\end{tabular}

Tabela 4 - Tabela de análise de variância (Anova-fator único) para SST

\begin{tabular}{cccccc}
\hline Fonte da variação & $\begin{array}{c}\text { Soma dos } \\
\text { quadrados }\end{array}$ & $\begin{array}{c}\text { Graus de } \\
\text { liberdade }\end{array}$ & $\begin{array}{c}\text { Quadrado } \\
\text { médio }\end{array}$ & $f_{\text {observado }}$ & $f_{\text {critico }}$ \\
\hline Entre grupos & 482 & 1 & 644 & 1,9 & 4,35 \\
Dentro dos grupos & 9860 & 20 & 334 & & \\
Total & 10342 & 21 & & & \\
\hline
\end{tabular}

de Cs entre os dois reatores, de $45 \%$ para 35 e de $57 \%$ para 70 dias de operação, corroboram com as afirmaçôes feitas. No entanto, apesar da diferença na estrutura da comunidade bacteriana e da diversidade populacional, apresentado pelo menor valor de similaridade, a eficiência da remoção de matéria orgânica (amostras brutas) foi semelhante, ou seja, eficiência média de remoção de matéria orgâ- nica de $60 \%$ nos dois reatores, após 70 dias de operação.

Com relação à análise da estrutura da comunidade microbiana do domínio Archaea observou-se no perfil das bandas padrões do DGGE (Figura 8) dos fragmentos do DNAr 16S amplificados por PCR pouca alteração na diversidade populacional em amostras temporais de 35 e 70 dias, em ambos reatores indivi- 


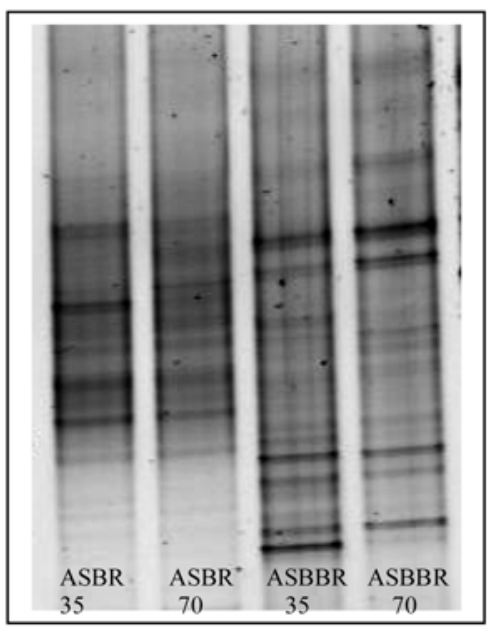

(Bacteria)

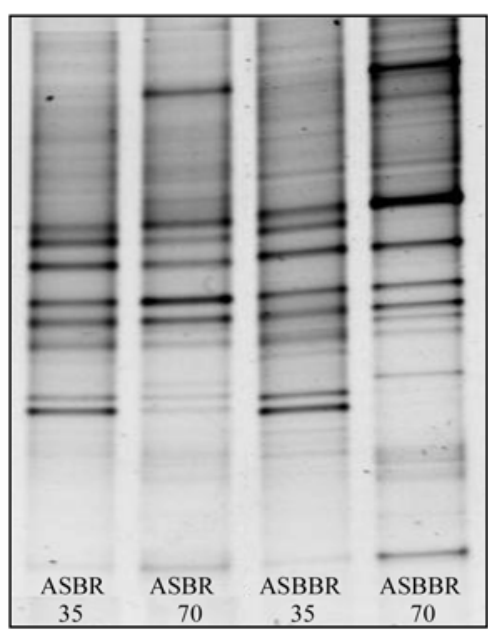

(Archaea)

Figura 8 - Perfil das bandas padrões do DGGE dos fragmentos do DNAr I6S amplificados com primers 968FGC e I392R (Domínio Bacteria) e com primer I I00FGC e I 400R (Domínio Archaea), utilizado nas amostras do reatores ASBR e ASBBR no 350 e 700 dia de operação

dualmente analisados. Esses resultados foram verificados pelo coeficiente de similaridade que foi de $85 \%$ para o ASBR e $70 \%$ para o ASBBR. Esta alteração pode estar relacionada à substituição de algumas populaçôes, principalmente no reator ASBBR (espuma de poliuretano), que apresentou o menor coeficiente de similaridade (70\%), no intervalo de 35 dias de operação, provavelmente, devido à destruição de grânulos realizada para possibilitar a imobilização de biomassa no meio suporte.

Pela comparação da comunidade do domínio Archaea entre os reatores ASBR e ASBBR em 35 dias de operação observou-se que não ocorreu mudança, inclusive confirmada pelo Cs que foi de $91 \%$, indicando semelhança na diversidade populacional nos sistemas. No entanto, $\mathrm{o}$ valor de Cs entre os dois reatores, de apenas $76 \%$ para 70 dias de operação, demonstra alteração na estrutura da comunidade após 35 dias de operação. Como houve a inoculação dos reatores, este resultado indica que populaçôes do domínio Archaea levaram mais tempo para se adaptarem depois da seleção dos grânulos (ASBR) e na imobilização da biomassa da espuma de poliuretano (ASBBR). Segundo Akarsubasi et al (2005), as variações no projeto do reator, condição de operação e a composição do afluente podem resultar em mudanças na comunidade microbiana presente em sistemas anaeróbios. Portanto, a avaliação das interações entre os microrganismos presen- tes torna-se importante, tanto no projeto, como no controle do reator anaeróbio.

\section{CONCLUSÕES}

Os reatores apresentaram em reduzido tempo de operação (10 a 20 dias) valores de eficiência média de remoção de matéria orgânica superior a $60 \%$ e valores de $\mathrm{DQO}_{\text {Brut }}$ no efluente ao redor

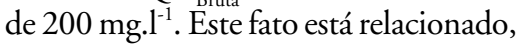
provavelmente, com a remoção física de sólidos na espuma de poliuretano no caso do ASBBR, enquanto que, para o ASBR, alia-se ao fato de o reator ter sido inoculado com lodo granular anaeróbio. O inicio do tratamento biológico pôde ser evidenciado pela presença de metano no biogás gerado na operação do ASBR, já no primeiro dia de operação, enquanto para o ASBBR após o $10^{\circ}$ dia de operação. Dessa forma, a adaptação dos reatores ao inóculo foi extremamente rápida, principalmente, para o ASBR. Foram atingidas eficiências médias de $60 \%$ de remoção de matéria orgânica expressa como DQO e superiores a $70 \%$ em termos de sólidos suspensos ao longo de toda etapa experimental.

Por meio das técnicas de biologia molecular detectou-se que as estruturas das comunidades domínio Bacteria presentes nos reatores no $35^{\circ}$ e $70^{\circ}$ dias de operação foram distintas, podendo-se inferir que a imobilização de biomassa empregada nas unidades pode ter proporcionado a seleção das populaçôes bacte- rianas diferentemente. Em relação ao domínio Archaea verificou-se maior similaridade na estrutura microbiana nos reatores, provavelmente devido ao fato de essas populações utilizarem substratos específicos formados ao final do processo anaeróbio.

Observou-se similaridade significativa no desempenho dos reatores ASBR e ASBBR no tratamento de esgoto sanitário independentemente da forma de imobilização de biomassa empregada (suporte inerte e biomassa granular). Tais configuraçôes demonstraram ter potencial como tecnologia anaeróbia para o tratamento desse tipo de água residuária. Logicamente, outros estudos devem ser direcionados visando, principalmente, a otimização de variáveis de operação, tais como, tempo de ciclo e velocidade de agitação, bem como a utilização de outros materiais suportes, a fim de maximizar o desempenho dos reatores.

No momento, a escolha da melhor opção de configuração está relacionada com o aspecto construtivo, já que o reator ASBBR para aplicação em maior escala exigiria maiores custos em função da aquisição e alocação no interior do reator do meio suporte, o que não ocorre no ASBR. Deve-se ressaltar que o ASBR apresenta o inconveniente de necessitar de biomassa granular desde o inicio de operação para o efetivo desempenho. Portanto, o estudo realizado possibilitou viabilizar o uso de reatores anaeróbios operados em bateladas seqüenciais, bem como a flexibilidade de 
opção na escolha da configuração para o tratamento de esgoto sanitário.

\section{AGRADECIMENTOS}

À Fundação de Amparo à Pesquisa do Estado de São Paulo (Processo $n^{\circ}$ 99/06152-8) e ao PRONEX (Programa de Núcleo de Excelência: Projeto $\left.\mathrm{n}^{\mathrm{o}} 664093 / 1997-3\right)$ pelo apoio financeiro na execução do trabalho.

\section{REFERÊNCIAS}

AKARSUBASI, A.T. et al. Effect of wastewater composition on archaeal population diversity. Water Research, v.39, p. 1576-1584, 2005.

APHA, AWWA, WPCF. Standard Methods for the examination of water and wastewater, $19^{\text {th }}$ edition, American Public Health Association, Washington, 1995.

DAGUE R.R., HABBEN C.E., PIDAPARTI S.R. Initial studies on the anaerobic sequencing batch reactor. Water Science and Technology, v.26, n.11, p. 2429-2432, 1992.

DILALLO, R. and ALBERTSON, O.E. Volatile acids by direct tritation. Journal WPCF, v.33, p.356-365, 1961.

FORESTI, E. et al. Reator anaeróbio horizontal de leito fixo (RAHLF) para tratamento de água residuária de induistria depapel reciclado. Revis- ta Brasileira dee Engenharia - Caderno de Engenharia Química, v12 v.12, p. 235-239, 1995.

GILLAN, D.C. et al. Genetic diversity of the biofilm covering Montacuta Ferruginosa (Mollusca, Bivalvia) as evaluated by denaturing gradient gel electrophoresis analysis and cloning of PCR-amplified gene fragments coding for 16SrRNA. Applied and Environmental Microbiology, v.64, p. 34643472, 1998.

KUDO, Y. et al. Methanogen flora of paddy soils in japan. FEMS Microbiol. Ecology, v. 22, p. 39-48, 1997.

MELVIN, A. N. G., HOBSON T. W., P.N. Identification of anaerobic digester bacteria using a polymerase chain reaction method. Bioresource Technology, v. 47, p. 73-80, 1994.

MUYZER, G., DE WAAL, E. C., UITTERLINDEN, A. G. Profiling of complex microbial populations by denaturing gradient gel electrophoresis analysis of polymerase chain reaction-amplified genes coding for $16 \mathrm{~S}$ rRNA. Applied and Environmental Microbiology, v.59, p. 695-700, 1993.

NIELSEN, T. A. et al. Identification of a novel group of bacteria in sludge from a deteriorated biological phosphorus removal reactor. Applied and Environmental Microbiology, v. 65, p. 1251-1258, 1999.

RATUSZNEI, S.M. et al. Feasibility of a stirred anaerobic sequencing batch reactor containing immobilized biomass for wastewater treatment. Bioresource Technology, v. 75, n. 2, p. 127$132,2000$.
RIBEIRO, R. et al. Influence of the carbon source on the anaerobic biomass adhesion on polyurethane foam matrices. Journal of Environmental Management, v.74, p. 187-194, 2005.

RIPLEY, L.E., BOYLE, W.C., CONVERSE, J.C. Improved alkalimetric monitoring for anaerobic digestion of high-strength wastes. Journal WPCF, v.58, p. 406-411, 1986.

Endereço para correspondência:

\section{Arnaldo Sarti}

Departamento de Hidráulica e Saneamento

EESC-USP

Av. Trabalhador Sãocarlense, 400 I 3566-590 São Carlos - SP - Brasil Tel.: (I6) 3373-9560

Fax: (I6) 3373-9550

E-mail: arnaldosarti@gmail.com

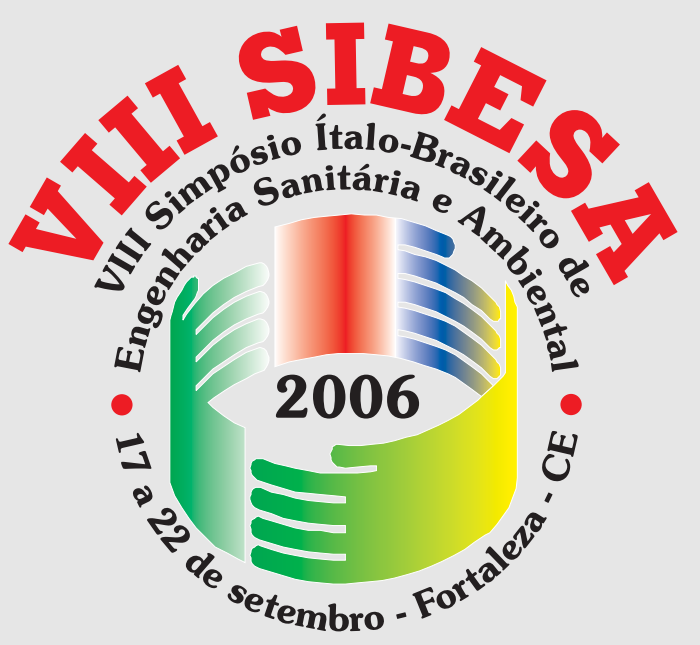

Marina Park Hotel

\section{"Mudanças Globais:} Desafios para o Saneamento Ambiental" 